\title{
Lipolytic Effects of Testosterone Hormone Replacement Therapy in A Rat Model of Andropause Versus Normal Controls
}

\author{
ALAA I. ALI, M.D.*; MAHMOUD M.A. ABULMEATY, M.D.** and EBTESAM M. IBRAHIM, M.D.** \\ The Departments of Clinical Pharmacology* and Medical Physiology**, Faculty of Medicine, Zagazig University
}

\begin{abstract}
Background: Testosterone (T) actions extend beyond the reproductive functions to include diverse metabolic pathways. Lipolytic effect of $\mathrm{T}$ is still underinvestigated, especially regarding the involved enzymes.

Aim of Study: This work measures two key lipolysisenzymes in both normal and orchiectomized rats with/withou $\mathrm{T}$ administration.

Material and Methods: Forty rats (200-300g) were subdivided into 4 equal groups (n=10/group); (A) Group I: Shamoperated control group. (B) Group II: Sham-operated rats were injected with IM testosterone undecanoate $(100 \mathrm{mg} / \mathrm{kg}$, for two weeks). (C) Group III: Andropause model was done by orchiectomy, (D) Group IV: Testosterone-replacement therapy in orchiectomized rats. T, Hormone-Sensitive Lipase (HSL), Adipocyte Triglyceride Lipase (ATGL), Free Fatty Acids (FFA), and lipid profile were measured using the commercially available ELISA kits. Food intake was measured manually in addition to body weight changes before during and after treatment. ANOVA with LSD post hoc test and Pearson correlation were used for analysis.
\end{abstract}

Results: The castrated rats showed lower food intake, lower body weight, and lower weight gain. Regarding adipose tissue lipolytic enzymes, ATGL was significantly decreased while both HSL and FFA were insignificantly changed. T replacement therapy in castrated rats increased blood products of lipolysis due to an increased level of ATGL, HSL, and FFA, in addition to the significant increase in food intake without significant wt changes. Similar effects were demonstrated in normal rats treated with $\mathrm{T}$.

Conclusion: T hormone therapy increased food intake, without significant changes in weight due to stimulation of lipolysis process mainly via stimulation of ATGL and HSL.

Key Words: Testosterone-Orchiectomy - Food intakeHormone-sensitive lipase - ATGL.

\section{Introduction}

MALE sex hormones especially testosterone play an important role not only in the regulation and control of the reproductive functions but their

Correspondence to: Dr. Mahmoud M.A. Abulmeaty, E-Mail: dr.abulmeaty@gmail.com action extend to include diverse metabolic pathways [1]. Testosterone is a steroid hormone mediates its action by binding to intracellular adrenergic receptors which bind to androgen response elements in the specific promoter regions of target genes which are responsible for the expression of a large number of diverse mediators secreted from different body organs and tissues [2]. Therefore, through its genetic and other rapid-onset non-genetic mechanisms, testosterone supposed to affect protein, carbohydrates and lipid metabolism [3]. At the target, tissues exert testosterone its action either directly or it could be metabolized through 5 a-reductase into Dihydrotestosterone (DHT) or by aromatized to estradiol (E2) which mediate their normal physiological effects through their own receptors [4].

Besides its physiological role as a naturallyoccurring hormone, testosterone is used in different dosage forms as a hormonal therapy either a replacement therapy in case of hypogonadism or in pharmacological doses in certain diseases e.g. breast cancer [5] .

The changes of serum lipid parameters under the testosterone therapy are variable [6]. Some studies reported a significant reduction in total cholesterol, low-density lipoprotein cholesterol and triglycerides under testosterone therapy either in healthy men or in patients with metabolic syndrome or type-2 diabetes mellitus [7,8]. Other studies report no changes in the lipid profile under the testosterone therapy [9]. The difference between these studies results could be referred to different doses or duration of action of testosterone or different ages of the population [6]. Moreover, the exact mechanisms whereby testosterone regulates the lipid metabolism are uncertain [10]. Therefore, this study tried to investigate the potential role of testosterone therapy on the lipid profile and the possible mechanisms for its effects through study- 
ing the potential changes in the key regulatory enzymes in lipid metabolism e.g. Adipocyte Triglyceride Lipase (ATGL) and Hormone-Sensitive Lipase (HSL) beside the changes in the amount of food intake and body changes in both normal and orchiectomized rats with/without testosterone administration.

\section{Material and Methods}

Animals and procedures: A total of forty adults, local strain, and male albino rats (240-280g) were obtained from the faculty of Pharmacy-Zagazig University, to be used in this study between June and August 2018. Rats were reared at a clean environment in groups of fives at the animal house (cage dimensions; 40, 30, and $18 \mathrm{~cm}$ ) with $12 \mathrm{~h}$ light/dark cycle, with free access to food and water. Room temperature was around $25^{\circ} \mathrm{C}$ and humidity between 20 and $45 \%$. All animals received care in accordance with the guide to the care and use of experimental animals of the Institute of Laboratory Animal Resources [11]. After the habituation period (one week), rats were subdivided into 4 equal groups ( $n=10 /$ each group). (A) Group I: Which behave as a normal control, in which sham operation was done through a scrotal incision and dissection of testes without excision, in addition to Intramuscular (IM) injection of normal saline $(0.3 \mathrm{ml})$. (B) Group II: Sham-operated rats which were injected with IM testosterone undecanoate (100mg/kg [12], for two weeks [13]). (C) Group III: Andropause rat model was done by orchiectomy, and treated with IM $0.3 \mathrm{ml}$ of normal saline. (D) Group IV: Testosterone-replacement therapy in orchiectomized rats in which rats induced andropause were managed by Testosterone replacement therapy by daily IM injection of the same dose and duration as Group II. Body weight $(\mathrm{g})$ in all groups was recorded firstly, before treatment, after treatment. Weight gain during the period of treatment was calculated by the difference between weights after and before the treatment period. Food intake measurement was obtained by recording the differences among everyday changes in food intake at 1PM [14].

Surgery: Intraperitoneal injection of thiopental $(40 \mathrm{mg} / \mathrm{kg})$ [15] was used for general anesthesia of rats. Anesthetized animals were fixed in the dorsal position, then the skin of the scrotum was disinfected with $70 \%$ Ethanol alcohol and a Tetracycline eye ointment was applied to the eyes to avoid damage of the cornea during anesthesia. In Groups III and IV, the linear incision and dissection in the ventral aspect of the scrotum to reach and open the tunicae. The main blood vessels were isolated and ligated by two ligations then cut were done at the lower end of the spermatic cord between these two ligations. Consequently, the testicle and epididymis were removed. The skin was sutured with the application of local antibiotic ointment over the sutures [16]. The sham operation for rats in Groups I and II included midline linear incision in the skin, subcutaneous tissues dissection to explore the testes without removal of any structures, then skin suture. To ensure the metabolic changes, rats were left for two weeks after orchiectomy [17], then the study protocols were applied.

Blood samples: After overnight fasting, approximately $5 \mathrm{~mL}$ of blood was withdrawn via cardiac puncture under light ether anesthesia. The blood was collected in heparinized tubes to be centrifuged for $15 \mathrm{~min}$ at $3000 \mathrm{rpm}$, and the plasma was collected and stored at $20^{\circ} \mathrm{C}$ until time of analysis.

Biochemical analysis: Measurement of lipid panel [Triglyceride (TG), Total Cholesterol (TC), High-Density Lipoprotein Cholesterol (HDL-C)] were assessed by the biochemistry analyzer [18] Additionally, Low-Density Lipoprotein Cholesterol (LDL-C), was calculated according to a simple accurate modified Friedewald equation [19]; LDL$\mathrm{C}=3 / 4$ (TC HDL-C), while Very Low-Density Lipoproteins (VLDL) were calculated by as $20 \%$ of TG [20] . The key lipolytic enzymes i.e. ATGL and HSL, were measured by Enzyme-Linked Immunosorbent Assay (ELISA) kits (catalog numbers; CSB-E14127r and CSB-EL012975RA, respectively, CUSABIO TECHNOLOGY LLC, USA), while Free Fatty Acids (FFA) level was measured by FFA colorimetric assay Kit (catalog number: MB S841629, Mybiosource, USA) [21]. Furthermore, measurement of total testosterone concentration was done by ELISA kits as reported previously [22], (catalog number K7418, BioVion, USA).

\section{Statistical analysis:}

The SPSS, Version 23 for Windows (SPSS Inc. Chicago, IL, USA), was used. The study variables were presented as the mean \pm SD. The ANOVA with LSD post hoc test was used to compare means of study groups. The relationships among the study variables were tested by the Pearson correlation coefficient. $p$-values $<0.05$ were considered to be significant.

\section{Results}

\section{Lipolytic status in the rat model of andropause:}

The castrated control rats (Group III) showed a lower food intake, lower body weight and lower weight gain (Table 1). Furthermore, rats with 
induced andropause represented with increases in total cholesterol, LDL, VLDL \& TG while HDL remained insignificantly changed. Regarding adi- pose tissue lipolytic enzymes, ATGL was significantly decreased while both HSL and FFA were insignificantly changed (Table 2).

Table (1): Testosterone, food intake and boy weights of all studied groups $(n=8)$.

\begin{tabular}{|c|c|c|c|c|}
\hline Parameters & Group I & Group II & GroupIII & GroupIV \\
\hline Body weight before $\mathrm{T}(\mathrm{g})$ & $268.67 \pm 16.77$ & $\begin{array}{l}264.00 \pm 10.53 \\
p=0.733 \mathrm{a}\end{array}$ & $\begin{array}{l}256.83 \pm 23.58 \\
p=0.391^{\mathrm{a}}\end{array}$ & $\begin{array}{l}257.00 \pm 35.21 \\
p=0.398 \mathrm{a} \\
p=0.990 \mathrm{~b}\end{array}$ \\
\hline Body weight after $\mathrm{T}(\mathrm{g})$ & $362.50 \pm 20.55$ & $\begin{array}{l}359.50 \pm 15.93 \\
p=0.871^{\mathrm{a}}\end{array}$ & $\begin{array}{l}327.50 \pm 29.58 \\
p=0.070 \mathrm{a}\end{array}$ & $\begin{array}{l}332.83 \pm 49.49 \\
p=0.120 \mathrm{a} \\
p=0.773 \mathrm{~b}\end{array}$ \\
\hline Weight gain $(\mathrm{g})$ & $93.83 \pm 6.97$ & $\begin{array}{l}95.50 \pm 8.41 \\
p=0.822 \mathrm{a}\end{array}$ & $\begin{array}{l}70.67 \pm 14.39 \\
p<0.05 \mathrm{a}\end{array}$ & $\begin{array}{l}75.83 \pm 17.77 \\
p<0.05 \mathrm{a} \\
p=0.488 \mathrm{~b}\end{array}$ \\
\hline Food intake $(\mathrm{g})$ & $25.25 \pm 10.01$ & $\begin{array}{l}41.63 \pm 5.87 \\
p<0.001^{\mathrm{a}}\end{array}$ & $\begin{array}{l}12.67 \pm 3.11 \\
p<0.05 \mathrm{a}\end{array}$ & $\begin{array}{l}31.67 \pm 4.07 \\
p=0.094 \mathrm{a} \\
p<0.001 \mathrm{~b}\end{array}$ \\
\hline Testosterone (ng/ml) & $7.74 \pm 1.09$ & $\begin{array}{l}16.24 \pm 2.55 \\
p<0.001^{\mathrm{a}}\end{array}$ & $\begin{array}{l}0.47 \pm 0.27 \\
p<0.001^{\mathrm{a}}\end{array}$ & $\begin{array}{l}5.10 \pm 1.47 \\
p<0.05 \mathrm{a} \\
p<0.001 \mathrm{~b}\end{array}$ \\
\hline
\end{tabular}

$\mathrm{a}=$ Significance versus Group I.

$\mathrm{b}=$ Significance versus Group III.

Table (2):Lipolysis parameters among studied groups ( $\mathrm{n}=8$ per each group).

\begin{tabular}{|c|c|c|c|c|}
\hline Parameters & Group I & Group II & Group III & Group IV \\
\hline Cholesterol (mmol/l) & $151.20 \pm 9.28$ & $\begin{array}{l}145.76 \pm 30.55 \\
p>0.05 a\end{array}$ & $\begin{array}{l}310.52 \pm 23.97 \\
p<0.001^{\mathrm{a}}\end{array}$ & $\begin{array}{l}167.60 \pm 12.98 \\
p>0.05 \mathrm{a} \\
p<0.001 \mathrm{~b}\end{array}$ \\
\hline LDL (mmol/l) & $88.55 \pm 5.41$ & $\begin{array}{l}54.13 \pm 23.98 \\
p<0.05 \mathrm{a}\end{array}$ & $\begin{array}{l}204.79 \pm 23.98 \\
p<0.001 \mathrm{a}\end{array}$ & $\begin{array}{l}78.11 \pm 23.3 \\
p>0.05 \mathrm{a} \\
p<0.001 \mathrm{~b}\end{array}$ \\
\hline $\mathrm{HDL}(\mathrm{mmol} / \mathrm{l})$ & $33.26 \pm 3.09$ & $\begin{array}{l}77.72 \pm 8.51 \\
p<0.001 \mathrm{a}\end{array}$ & $\begin{array}{l}38.45 \pm 6.19 \\
p>0.05 a\end{array}$ & $\begin{array}{l}69.61 \pm 10.83 \\
p<0.001 \mathrm{a} \\
p<0.001 \mathrm{~b}\end{array}$ \\
\hline VLDL (mmol/l) & $25.20 \pm 2.32$ & $\begin{array}{l}13.01 \pm 5.02 \\
p<0.01 \mathrm{a}\end{array}$ & $\begin{array}{l}50.70 \pm 0.39 \\
p<0.01 \mathrm{a}\end{array}$ & $\begin{array}{l}24.53 \pm 3.09 \\
p>0.05 \mathrm{a} \\
p<0.001 \mathrm{~b}\end{array}$ \\
\hline $\mathrm{TG}(\mathrm{mmol} / \mathrm{l})$ & $127.54 \pm 26.57$ & $\begin{array}{l}69.22 \pm 6.19 \\
p<0.01 \mathrm{a}\end{array}$ & $\begin{array}{l}253.31 \pm 56.68 \\
p<0.001^{\mathrm{a}}\end{array}$ & $\begin{array}{l}120.80 \pm 33.66 \\
p>0.05 \mathrm{a} \\
p<0.001 \mathrm{~b}\end{array}$ \\
\hline HSL (pg/ml) & $122.45 \pm 4.88$ & $\begin{array}{l}158.71 \pm 16.04 \\
p<0.05 \mathrm{a}\end{array}$ & $\begin{array}{l}119.33 \pm 3.92 \\
p>0.05 \mathrm{a}\end{array}$ & $\begin{array}{l}163.11 \pm 13.61 \\
p<0.05 \mathrm{a} \\
p<0.05 \mathrm{~b}\end{array}$ \\
\hline ATGL (ng/ml) & $4.96 \pm 0.38$ & $\begin{array}{l}22.98 \pm 1.68 \\
p<0.001^{\mathrm{a}}\end{array}$ & $\begin{array}{l}6.77 \pm 2.06 \\
p<0.05 \mathrm{a}\end{array}$ & $\begin{array}{l}25.85 \pm 1.44 \\
p<0.001^{\mathrm{a}} \\
p<0.001 \mathrm{~b}\end{array}$ \\
\hline FFA (ng/dl) & $493.16 \pm 10.94$ & $\begin{array}{l}561.67 \pm 6.83 \\
p<0.001^{\mathrm{a}}\end{array}$ & $\begin{array}{l}496.37 \pm 13.62 \\
p>0.05 a\end{array}$ & $\begin{array}{l}573.96 \pm 12.61 \\
p<0.001^{\mathrm{a}} \\
p<0.001 \mathrm{~b}\end{array}$ \\
\hline $\begin{array}{ll}\text { LDL } & : \text { Low-Density Li } \\
\text { HDL } & : \text { High-Density L } \\
\text { VLDL }: \text { Very Low-Den } \\
\text { TG } \quad: \text { Triglycerides. } \\
\text { HSL } & : \text { Hormone-Sensi }\end{array}$ & $\begin{array}{l}\text { otein. } \\
\text { rotein. } \\
\text { ipoprotein. } \\
\text { inase }\end{array}$ & & \multicolumn{2}{|c|}{$\begin{array}{ll}\text { ATGL: Adipocyte Triglycerides Lipase. } \\
\text { FFA } & \text { : Free Fatty Acids. } \\
\text { a } & : \text { Significance versus Group I. } \\
\text { b } & \text { : Significance versus Group III. }\end{array}$} \\
\hline
\end{tabular}


Effect of $T$ therapy on lipolytic enzymes, and substrates' concentrations: The VLDL, LDL, and TG were significantly lower $(p<0.05)$, while HDL was significantly higher $(p<0.001)$ with insignificant changes in total cholesterol in Group II vs. normal rats in Group I. Additionally, both HSL, and ATGL in addition to FFA concentrations were significantly increased (Table 2). Regarding treated rats with andropause (Group IV), TRT produced a significant increase in HDL level, in addition to significant reductions in levels of total cholesterol, LDL, VLDL, and TG. In adipose tissue, TRT produced a significant increase in ATGL and HSL levels with the subsequent rise of the level FFA.

Changes in food intake and body weight: Regarding food intake and body weight gain, they were significantly decreased by orchiectomy and $\mathrm{T}$ treatment fail to increase the weight gain (Group II vs. Group I; $p>0.05)$, despite improvement of food intake. Mean worthy, rats in Group IV also showed significant improvement in food intake with insignificant weight changes in comparison with the Group III.

Association of T level with the key lipolytic enzymes:

As shown in figures 1-4, $\mathrm{T}$ has a strong positive correlation with ATGL in all groups ( $r=0.639$, $r=0.857, r=0.710, r=0.697$ and $p<0.05$, in Groups I, II, III, and IV, respectively). However, the correlation with HSL was insignificant in all studied androgenic levels.

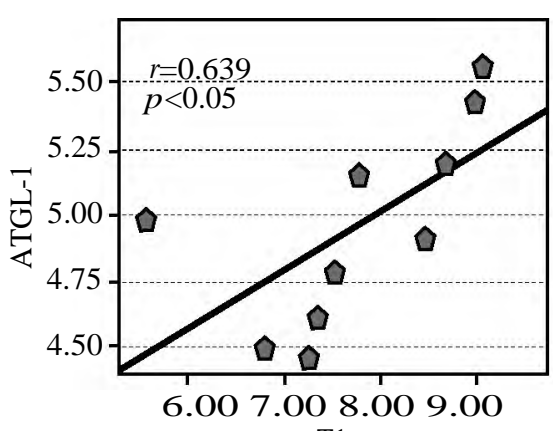

$\mathrm{T} 1$

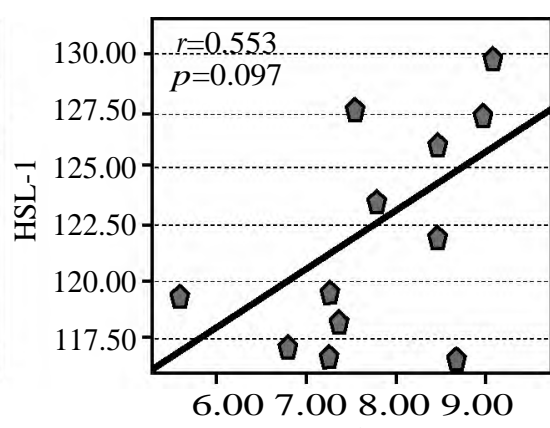

$\mathrm{T} 1$

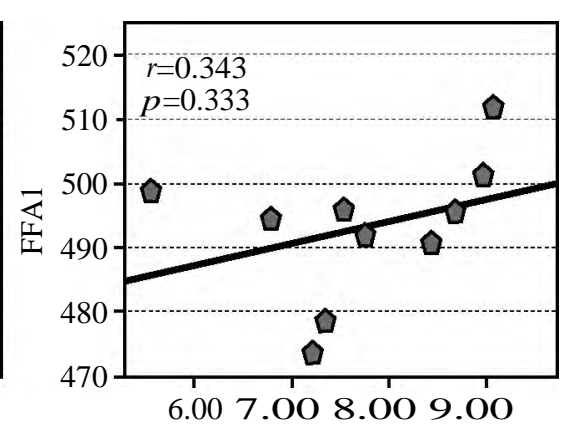

$\mathrm{T} 1$

Fig. (1): Correlations of $\mathrm{T}$ with the key lipolytic enzymes and free fatty acid levels in Group I.
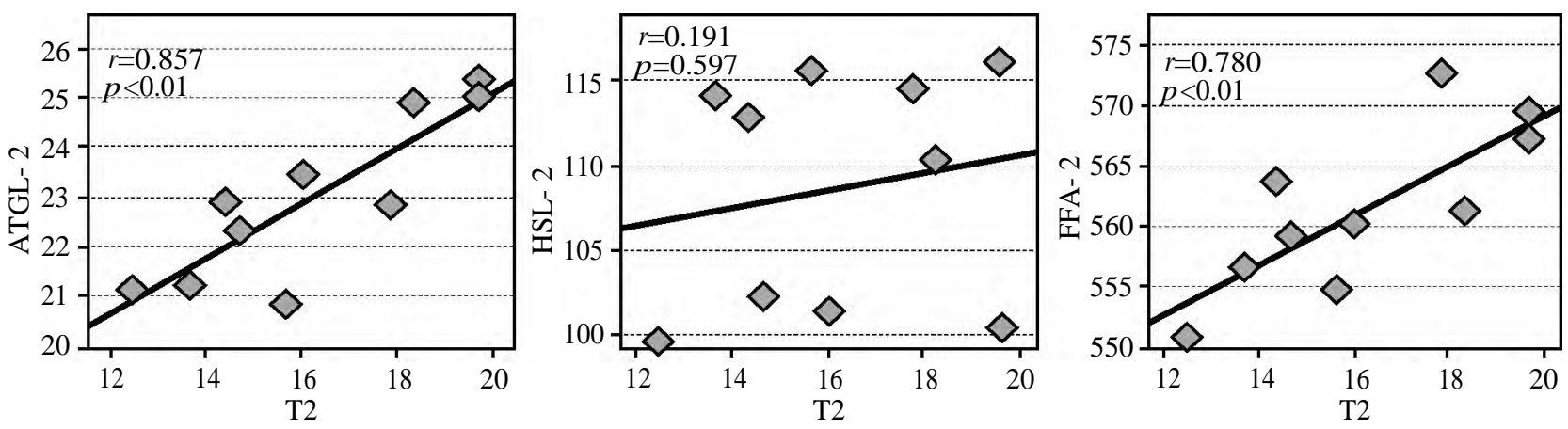

Fig. (2): Correlations of T with the key lipolytic enzymes and free fatty acid levels in Group II.
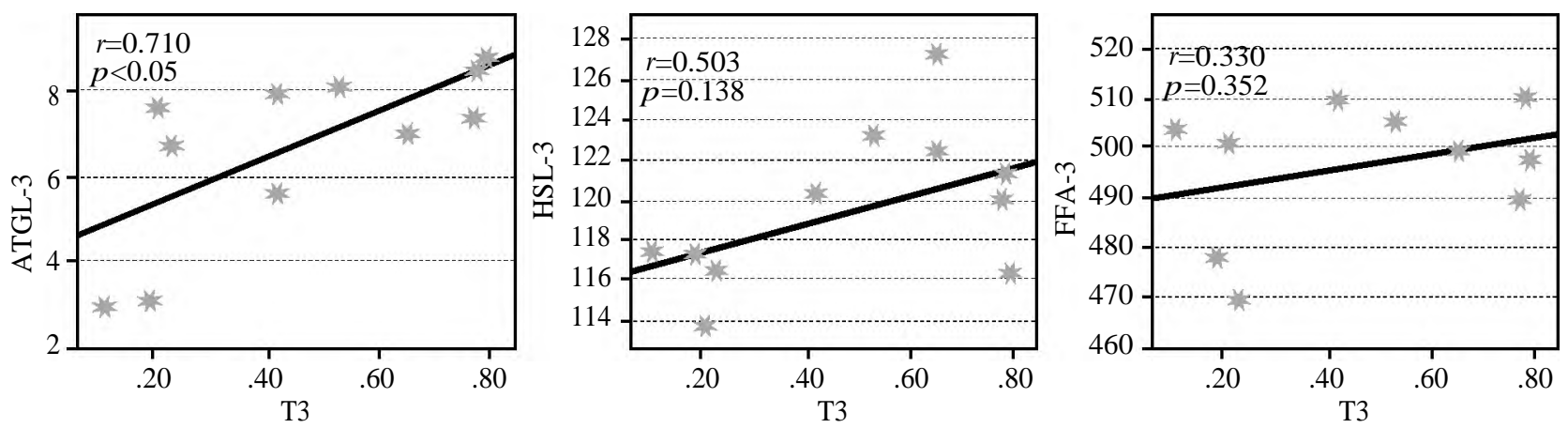

Fig. (3): Correlations of $\mathrm{T}$ with the key lipolytic enzymes and free fatty acid levels in Group III. 

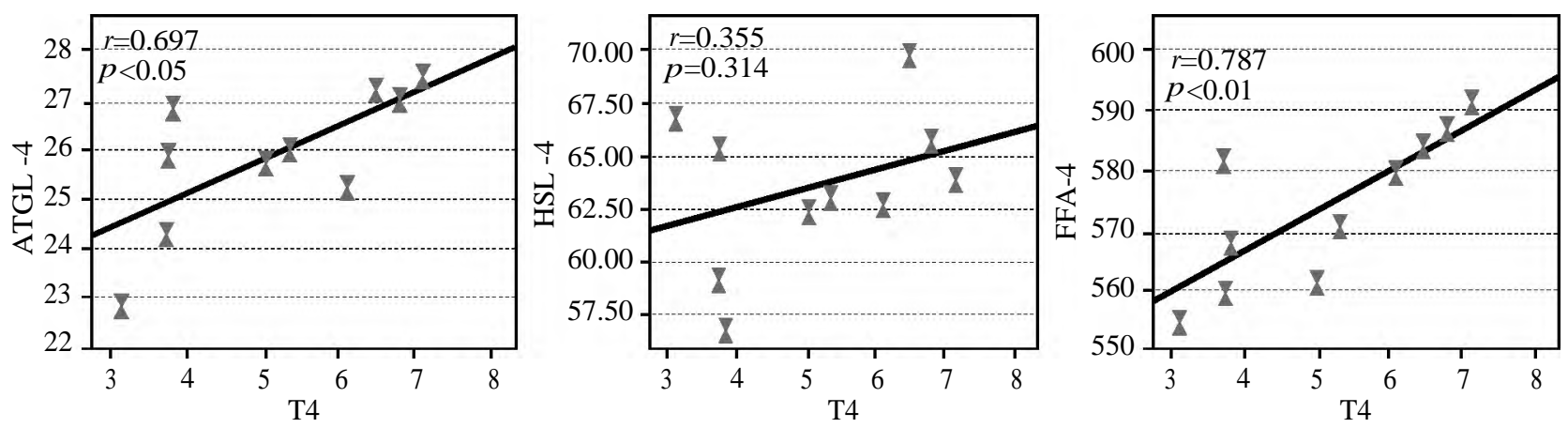

Fig. (4): Correlations of T with the key lipolytic enzymes and free fatty acid levels in Group IV.

\section{Discussion}

Several clinical and experimental studies have reported that testosterone plays an important role in the regulation of different metabolic pathways especially lipid metabolism. The ability of testosterone to share in the control of metabolic pathways mediated mainly through different mediators [23].

The results of this study showed a marked reduction in food intake in testosterone-deficient rats in comparison to the control group which is markedly recovered with testosterone replacement therapy. This orexigenic effect could be explained by the action of testosterone and/or its active metabolite estradiol on the genetic regulation of nesfatin-1. Recently, Seon et al., [24] concluded that testosterone plays an essential role in nesfatin1 regulation whereby the level of expression of nesfatin-1 mRNA in the pituitary gland is reduced significantly after castration with subsequent reduction in the amount of food intake and body weight. On the other hand, testosterone replacement therapy restored the normal level of expressed nesfatin-1 in pituitary gland which enabled the mice to regain their normal eating behavior. Interestingly, Prinz et al., [25] reported that nesfatin-1 which is secreted from the digestive system controls the amount of food intake not only through regulation of gastric motility but through a direct effect in certain brain areas. Furthermore, $\mathrm{T}$ regulates the eating behavior through other different mediators such as ghrelin. Through their action at specific receptors in the arcuate nucleus stimulate ghrelin molecules the appetite and increase the amount of food intake [26]. Greenman et al., [27] claimed that a strong positive correlation exists between testosterone and ghrelin not only in men but also in postmenopausal women and the role of testosterone in the regulation of eating behavior is mediated partially through ghrelin.
The metabolic action of testosterone and its effect on the lipid panel is an interesting point in many research activities. Many clinical and experimental studies revealed a strong negative correlation between the serum testosterone level and both total cholesterol and LDL cholesterol levels [23].

Lee et al., [28] showed that the serum cholesterol level is markedly elevated in testosterone-deficient mice moreover testosterone therapy succeeded to decrease the serum level of total and LDL cholesterol. In agreement with these findings Hatch et al., [29] reported that the serum concentrations of cholesterol and triglycerides in castrated mice are markedly elevated with subsequent formation of atherosclerotic lesions in comparison to control group. The results of the current study showed also the significant elevation of LDL cholesterol, VLDL cholesterol and triglycerides levels in testosteronedeficient rats (Group III) in comparison to normal and testosterone-treated groups. However, the exact mechanisms whereby testosterone regulates the cholesterol metabolism still uncertain. Cai et al., [30] studied the potential mechanisms of testosterone effects on cholesterol metabolism in pigs. They have been concluded that testosterone deficiency induces hypercholesterolemia through alteration of gene expression of specific proteins involved in lipoprotein assembly and secretion. The results of their study showed a significant reduction of LDL Receptors (LDLR) expression in the liver of testosterone-deficient pigs. The reduction of LDLR leads to decline in LDL cholesterol uptake and clearance through the liver. The cause of LDLR reduction, in that case, was the overexpression of Proprotein Convertase Subtilisin/Kexin type 9 (PCSK9), PCSK9 is a proprotein convertase enzyme expressed in different tissues especially in the liver. In the liver bind PCSK9 molecules to LDLR inhibiting its ability to bind to and uptake of LDL molecules [31]. The findings of Cai et al., [30] intensify our assumption that testosterone decreases serum cholesterol level through alteration 
of gene expression of LDLR and post-receptor regulatory protein e.g. PCSK9.

As we mentioned above, testosterone increases the appetite through different mediators mainly nesfatin- 1 and ghrelin which explained some findings of present study whereby the testosteronetreated groups showed a significant increase in the amount of food intake in comparison to the testosterone-deficient group. Despite this increase in the food intake showed the testosterone-treated group no significant increase in body weight in comparison to the testosterone-deficient group. We assumed a potential effect of testosterone on the lipid metabolizing enzymes as a part of its action on lipid metabolism. According to the best of our knowledge the effect of androgens on the lipases still a matter of controversy. Heemres et al., [32] reported that testosterone deficiency in rats resulted in marked decrease in the mRNA and protein levels of certain genes involved in fatty acids and cholesterol synthesis e.g. fatty acid synthetase and HMG-CoA-reductase. Moreover, the re-administration of testosterone in these rats restored the normal expression of the affected genes increasing the level of lipid synthesis and proving a lipogenic effect of testosterone. Furthermore, Münzker et al., [33] reported that androgen could promote the development of Non-Alcoholic Fatty Liver Diseases (NAFLD) as they facilitate hepatic lipogenesis and the testosterone/Dehydroepiandrosterone ratio is an important determinable factor in the development of NAFLD than the initial concentration of either testosterone or Dehydroepiandrosterone alone.

Therefore this study explored the effect of testosterone on certain key regulatory enzymes in lipid metabolism in order to identify which metabolic pathways could be regulated, even partially, through testosterone. The results in the testosteronetreated groups; either the healthy group (Group II) or the testosterone-substituted group (Group IV) showed a significant increase in the concentration of ATGL, HSL, and FFA in comparison to the testosterone-deficient group (Group III). Furthermore, there were positive correlations between testosterone level and the concentrations of ATGL, HSL, and FFA with different levels of significance. Interestingly the results of the current study showed also an increase in HSL and ATGL concentrations in the Group II in comparison to the control group (Group I), which indicate an effect of testosterone on the tissue lipases even in non-physiological doses. These results are in accordance with the result of Karbowska and Kochan [34] who reported that Dehydroepiandrosterone (DHEA), active me- tabolite of testosterone, increases lipid mobilization in adipose tissue with subsequent reduction in body fat in rodent and human as a result of enhanced activity and expression of both AGTL and HSL which supposed to be mediated, at least partially, through PPAR 2 which upregulates the genetic expression of both AGTL and HSL. On the other hand, Lee et al., [35] reported that androgen upregulates the adrenergic receptors in adipose tissue which facilitate the action of catecholamines inducing lipolysis. All these findings intensify our assumption that testosterone therapy has not only a negative effect on lipogenesis but it stimulates also lipolysis.

In conclusion, the results of the current study could approve that testosterone-replacement therapy increases the lipolysis through activating some key regulatory enzymes e.g. ATGL and HSL which explained the failure in body gain in spite of excessive food intake. However, his study has some limitation especially absent measurement of energy expenditure and orexigenic mediators such as Nesfatin-1 and ghrelin. Future studies may give proper answers regarding these issues.

\section{References}

1- MORGENTALER A., MINER M.M., CALIBER M., GUAY A.T., KHERA M. and TRAISH A.M.: Testosterone Therapy and Cardiovascular Risk: Advances and Controversies. Mayo. Clinic. Proceedings, 90 (2): 224-51. https://. doi.org/10.1016/j.mayocp.2014.10.011, 2015.

2- YASSIN A.A., SAAD F. and GOOREN L.J.: Metabolic syndrome, testosterone deficiency and erectile dysfunction never come alone. Andrologia, 40 (4): 259-264. https://. doi.org/10.1111/j.1439-0272.2008.00851.x. 2008.

3- HAMILTON E.J., GIANATTI E., STRAUSS B.J., WENTWORTH J., LIM-JOON D., BOLTON D., ZAJAZC J.D., and GROSSMANN M.: Increase in visceral and subcutaneous abdominal fat in men with prostate cancer treated with androgen deprivation therapy. Clinical Endocrinology, 74 (3): 377-83. https://doi.org/10.1111/j.1365-2265 2010.03942.x, 2011.

4- MARKS L.S.: 5 alpha-reductase: History and clinical importance. Reviews in Urology, 6 Suppl 9 (Suppl 9): S11-21. 2004.

5- ZAROTSKY V., HUANG M.Y., CARMAN W., MORGENTALER A., SINGHAL P.K., COFFIN D. and JONES T.H.: Systematic literature review of the risk factors, comorbidities, and consequences of hypogonadism in men. Andrology, 2 (6): 819-834. https://doi.org/10.1111/ andr.274, 2014.

6- JONES T.H. and KELLY D.: Randomized controlled trials-mechanistic studies of testosterone and the cardiovascular system. Asian Journal of Andrology, 20 (2): 120. https://doi.org/10.4103/aja.aja 6 18, 2018.

7- CORNOLDI A., CAMINITI G., MARAZZI G., VITALE C., PATRIZI R., VOLTERRANI M., MICELI M., FINI M., SPERA G. and ROSANO G.: Effects of chronic 
testosterone administration on myocardial ischemia, lipid metabolism and insulin resistance in elderly male diabetic patients with coronary artery disease. International Journal of Cardiology, 142 (1): 50-5. https://doi.org/10.1016/ J.IJCARD.2008.12.107, 2010.

8- HACKETT G., COLE N., BHARTIA M., KENNEDY D., RAJU J., WILKINSON P. and The Blast Study Group: Testosterone Replacement Therapy Improves Metabolic Parameters in Hypogonadal Men with Type 2 Diabetes but Not in Men with Coexisting Depression: The BLAST Study. The Journal of Sexual Medicine, 11 (3): 840-56. https://doi.org/10.1111/jsm.12404, 2014.

9- HUO S., SCIALLI A.R., MCGARVEY S., HILL E., TÜGERTIMUR B., HOGENMILLER A., HIRSCH A.I., and FUGH-BERMAN A.: Treatment of Men for "Low Testosterone": A Systematic Review. PLOS ONE, 11 (9): e0162480. https://doi.org/10.1371/journal.pone.0162480, 2016.

10- KELLY D.M., AKHTAR S., SELLERS D.J., MURALEEDHARAN V., CHANNER K.S. and JONES T.H.: Testosterone differentially regulates targets of lipid and glucose metabolism in liver, muscle and adipose tissues of the testicular feminised mouse. Endocrine, 54 (2): 50415. doi: 10.1007/s12020-016-1019-1, 2016.

11- Institute of Laboratory Animal Resources, Commision on Life Sciences and National Research Council: Guide for the care and use of laboratory animals, 8 th Edition. National academy press, Washington DC, 21-55, 1996.

12- CUI K., LI R., ZHANG Y., WANG T., WANG S.G., YE Z.Q., RAO K. and LIU J.H.: Androgen may improve erectile function in castrated rats by regulating the ERK1/2 pathway. Zhonghua Nan Ke Xue, 21 (11): 967-72, 2015.

13- WARD G.R. and ABDEL-RAHMAN A.A.: Effect of testosterone replacement or duration of castration on baroreflex bradycardia in conscious rats. BMC Pharmacol. https://doi:10.1186/1471-2210-5-9, 2005.

14- HIGUCHI K., MASAKI T., GOTOH K., CHIBA S., KATURAGI I., TANAKA K., KAKUMA T. and YOSHIMATSU H.: Apelin, an APJ receptor ligand, regulates body adiposity and favors the messenger ribonucleic acid expression of uncoupling proteins in mice, Endocrinology, 148: 2690-7, 2007.

15- The Laboratory Rat (Second Edition): Anesthesia and Analgesia. American College of Laboratory Animal Medicine 627-664. https://doi.org/10.1016/B978-0120749034/50022-4, 2006.

16- IDRIS A.I.: Ovariectomy/orchidectomy in rodents. Methods Mol. Biol., 816: 545-51, 2012.

17- MOGHADAMI S., JAHANSHAHI M., SEPEHRI H. and AMINI H.: Gonadectomy reduces the density of androgen receptor-immunoreactive neurons in male rat's hippocampus: Testosterone replacement compensates it. Behav. Brain. Funct., 12 (1): 5-10, 2016.

18- DING L., QU Z., CHI J., SHI R., WANG L., HOU L., WANG Y. and PANG S.: Effects of preventative application of metformin on bile acid metabolism in high fatfed/streptozotocin-diabetic rats. Int. J. Clin. Exp. Pathol., 8 (5): 5450-6, 2015.

19- De CORDOVA C.M.M. and De CORDOVA M.M.: A new accurate, simple formula for LDL-cholesterol estimation based on directly measured blood lipids from a large cohort. Ann. Clin. Biochem., 50: 13-9, 2013.

20- CHEN Y., ZHANG X., PAN B., JIN X., YAO H., CHEN B., ZOU Y., GE J. and CHEN H.: A modified formula for calculating low-density lipoprotein cholesterol values. Lipids Health Dis. https://doi:10.1186/1476-511X-9-52, 2010.

21- AHMED S., BOTT D., GOMEZ A., TAMBLYN L., RASHEED A., CHO T., MAC-PHERSON L., SUGAMORI K.S., YANG Y., GRANT D.M., CUMMINS C.L. and MATTHEWS J.: Loss of the Mono-ADP-ribosyltransferase, Tiparp, Increases Sensitivity to Dioxin-induced Steatohepatitis and Lethality. J. Biol. Chem., 290 (27): 16824 40, 2015.

22- NJOROGE R.W., MACHARIA B.N., SAWEC D.J. and MAIYOH G.K.: Effects of crude kerosene on testosterone levels, aggression and toxicity in rat. Toxicology Reports, 2: 175-83, 2015.

23- ISIDORI A.M., GIANNETTA E., GRECO E.A., GIANFRILLI D., BONIFACIO V., ISIDORI A., LENZI A. and FABBRI A.: Effects of testosterone on body composition, bone metabolism and serum lipid profile in middle-aged men: A meta-analysis. Clinical Endocrinology, 63 (3): 280-93. https://doi.org/10.1111/j.1365-2265.2005 . 02339 $\mathrm{x}, 2005$.

24- SEON S., JEON D., KIM H., CHUNG Y., CHOI N. and YANG H.: Testosterone Regulates NUCB2 mRNA Expression in Male Mouse Hypothalamus and Pituitary Gland. Development \& Reproduction, 21 (1): 71-8, https:// doi.org/10.12717/DR.2017.21.1.071, 2017

25- PRINZ P., GOEBEL-STENGEL M., TEUFFEL P., ROSE M., KLAPP B.F. and STENGEL A.: Peripheral and central localization of the nesfatin-1 receptor using autoradiography in rats. Biochemical and Biophysical Research Communications, 470 (3): 521-7. https://doi.org/ 10.1016/ j.bbrc.2016.01.113, 2016.

26- TOLLE V., BASSANT M.-H., ZIZZARI P., POINDESSOUS-JAZAT F., TOMASETTO C., EPELBAUM J. and BLUET-PAJOT M.T.: Ultradian Rhythmicity of Ghrelin Secretion in Relation with G.H., Feeding Behavior, and Sleep-Wake Patterns in Rats. Endocrinology, 143 (4): 1353-61. https://doi.org/10.1210/endo.143.4.8712, 2002.

27- GREENMAN Y., ROUACH V., LIMOR R., GILAD S., and STERN N.: Testosterone Is a Strong Correlate of Ghrelin Levels in Men and Postmenopausal Women. Neuroendocrinology, 89 (1): 79-85. https://doi.org/ 10.1159/000151768, 2009.

28- LEE C.E., KANG J.S. and KIM K.I.: Effects of Gender, Gonadectomy and Sex Hormones on Growth and Plasma Cholesterol Level in Rats. Annals of Nutrition and Metabolism, 53 (1): 1-5. https://doi.org/10.1159/000152867, 2008 .

29- HATCH N.W., SRODULSKI S.J., CHAN H.-W., ZHANG X., TANNOCK L.R. and KING V.L.: Endogenous Androgen Deficiency Enhances Diet-Induced Hypercholesterolemia and Atherosclerosis in Low-Density Lipoprotein Receptor-Deficient Mice. Gender Medicine, 9 (5): 319 28. https://doi.org/10.1016/j.genm.2012.08.003, 2012

30- CAI Z., XI H., PAN Y., JIANG X., CHEN L., CAI Y., ZHU K., CHEN C., XU X. and CHEN M.: Effect of testosterone deficiency on cholesterol metabolism in pigs 
fed a high-fat and high-cholesterol diet. Lipids in Health and Disease, 14 (1): 18. https://doi.org/10.1186/s12944015-0014-5, 2015.

31- WEINREICH M. and FRISHMAN W.H.: Antihyperlipidemic Therapies Targeting PCSK9. Cardiology in Review, 22 (3): 140-6. https://doi.org/10.1097/CRD.0000000 $000000014,2014$.

32- HEEMERS H., VANDERHOYDONC F., ROSKAMS T., SHECHTER I., HEYNS W., VERHOEVEN G. and SWINNEN J.V.: Androgens stimulate coordinated lipogenic gene expression in normal target tissues in vivo. Molecular and Cellular Endocrinology, 205 (1-2): 21-31, 2003.

33- MÜNZKER J., HOFER D., TRUMMER C., ULBING M., HARGER A., PIEBER T., OWEN L., KEEVIL B., BRABANT G., LERCHBAUM E. and OBERMAYER-
PIE-TSCH B.: Testosterone to Dihydrotestosterone Ratio as a New Biomarker for an Adverse Metabolic Phenotype in the Polycystic Ovary Syndrome. The Journal of Clinical Endocrinology \& Metabolism, 100 (2): 653-60. https://. doi.org/10.1210/jc.2014-2523, 2015.

34- KARBOWSKA J. and KOCHAN Z.: Fat-reducing effects of dehydroepiandrosterone involve upregulation of ATGL and HSL expression, and stimulation of lipolysis in adipose tissue. Steroids, 77 (13): 1359-65. https://doi.org/ 10.1016/ j. steroids. 2012.08.002, 2012.

35- LEE M.J., WU Y. and FRIED S.K.: Adipose tissue heterogeneity: Implication of depot differences in adipose tissue for obesity complications. Molecular Aspects of Medicine, 34 (1): 1-11. https://doi.org/10.1016/j . mam. 2012.10.001, 2013.

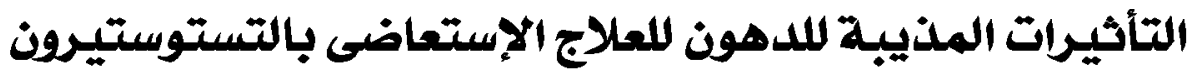

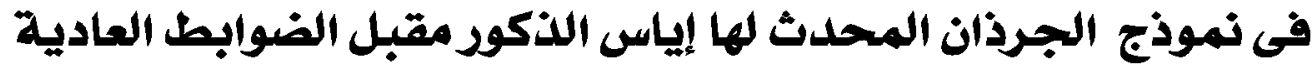

خلفية البحث: تمتد تأثيرات التستوستيرن إلى ما وراء وظائف التكاثر لتشمل مسارات التمثيل الغذائى المتنوعة، لا يزال تأثيّر التستوستيرين على إذابة الدهون تحت الأختبار، خاصية فيما يتعلق بالأنزيمات المعنية.

الهدف من الدراسة: يقيس هذا العمل مستويات أثثين من إنزيمات تحلل الدهون الرئيسية فى كل من الفئران الطبيعية والمحدث لها يأس الذكور مع أو بدون إعطاء التستوستيرني.

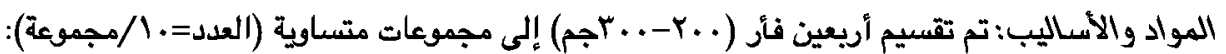

أ- المجموعة الأولى : جموعة ضابطة أحدث لها عملية غير حقيقية لم يحدث خلالها إزالة الخصية الفية. ب- المجموعة الثانية: تم حقن الفئران التى لم تستأصل خصيتهم عن طريق العضل بإستخدام دواء الديستسترون بجرعة ـ. ـاملجرام لكل كيلو جرام من عنغ الفئران لمدة أسبوعين. ج المجموعة الثالثة: تم إنتاج نموذج الإياس عن طريق إستئصال الخصية. د- المجموعة الرابعة: العلاج الإستعاضى بالتستوستيرون فى الجرذان البانس عن المخصية.

ثم تم ثياس مستوى التستوستيرون، الإنزيم المذيب اللدهون الحساس للهرمونات (HSL)، والإنزيم المذيب اللدهون الثحمية فى الخايا

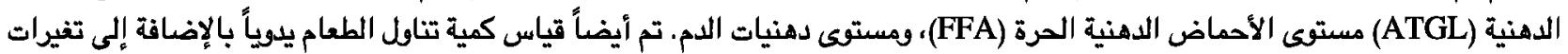
ونن الجسم قبل وخلال فترة العلاج وبعدها . تم إستخدام سبل التحليل الإحصائى المناسبة. النتائج: أظهرت الفئران المخصية تناول كمية أقل من الطعام، وإنخفاض فى ونن الجسم، وضعف أكتساب الونن. فيما يتعلق بالأنزيمات

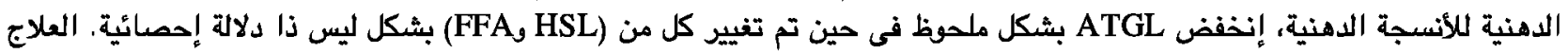

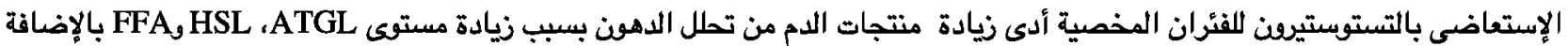
إلى الزيادة الكبيرة فى تناول الطعام لون تغييرات كبيرة بالوذن. وقد أظهرت آثار ممائة فى الفئران العادية المحقونة بالتستوستيرني.

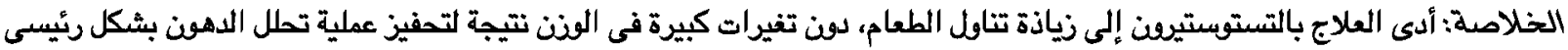
من خلال زيادة هستوى الإنزيم المذيب اللدهون الحساس اللهرمونات والإنزيم المذيب اللدهون الثحمية الثلاثية في الخلايا الدهنية. 